Meta

Journal des traducteurs

Translators' Journal

\title{
Monitoring Processes in Conference Interpreting: Towards a model for interpreter-trainees \\ Towards a Monitoring Model for Interpreter-Trainees
}

\section{David Sawyer}

Volume 39, numéro 3, septembre 1994

URI : https://id.erudit.org/iderudit/004035ar

DOI : https://doi.org/10.7202/004035ar

Aller au sommaire du numéro

\section{Éditeur(s)}

Les Presses de l'Université de Montréal

ISSN

0026-0452 (imprimé)

1492-1421 (numérique)

Découvrir la revue

Citer cet article

Sawyer, D. (1994). Monitoring Processes in Conference Interpreting: Towards a model for interpreter-trainees / Towards a Monitoring Model for Interpreter-Trainees. Meta, 39(3), 433-438. https://doi.org/10.7202/004035ar

\section{Résumé de l'article}

Cet article postule que des processus de contrôle interviennent dans l'interprétation de conférences et qu'il existe un équilibre indispensable entre les différentes tâches, c'est-à-dire entre l'écoute, le contrôle et l'expression. Cet équilibre doit être atteint pour obtenir une interprétation de qualité élevée. Le fait d'attirer l'attention des étudiants-interprètes sur les rôles conscients et inconscients des processus de contrôle leur permet d'augmenter leur compréhension des facteurs influençant leurs performances. En affirmant leur maîtrise de ces processus de contrôle, les étudiants peuvent se concentrer sur les domaines dans lesquels ils sont les plus faibles. En général, la prise de conscience des processus de contrôle peut améliorer l'équilibre des efforts requis pour une activité multi-tâches et, en retour, aider à un meilleur usage des capacités mentales disponibles. Elle permet aux étudiants-interprètes d'atteindre plus facilement l'objectif d'une interprétation consécutive et simultanée de bonne qualité. 


\title{
MONITORING PROCESSES IN CONFERENCE INTERPRETING: TOWARDS A MODEL FOR INTERPRETER-TRAINEES'
}

\author{
DAVID SAWYER \\ Fachbereich für Angewandte Sprach - und \\ Kulturwissenschaft Universität Mainz, Germersheim, Deutschland
}

\begin{abstract}
Résumé
Cet article postule que des processus de contrôle interviennent dans l'interprétation de conférences et qu'il existe un équilibre indispensable entre les différentes tâches, c'est-à-dire entre l'écoute, le contrôle et l'expression. Cet équilibre doit être atteint pour obtenir une interprétation de qualité élevée. Le fait d'attirer l'attention des étudiants-interprètes sur les rôles conscients et inconscients des processus de contrôle leur permet d'augmenter leur compréhension des facteurs influençant leurs performances. En affirmant leur maîtrise de ces processus de contrôle, les étudiants peuvent se concentrer sur les domaines dans lesquels ils sont les plus faibles. En général, la prise de conscience des processus de contrôle peut améliorer l'équilibre des efforts requis pour une activité multi-tâches et, en retour, aider à un meilleur usage des capacités mentales disponibles. Elle permet aux étudiants-interprètes d'atteindre plus facilement l'objectif d'une interprétation consécutive et simultanée de bonne qualité.
\end{abstract}

\section{INTRODUCTION}

Interpreter-trainees are often given advice in class similar to the following: listen more closely to what you are producing; keep one ear uncovered when doing simultaneous; if you cannot think of a word sit back for a micro-second and think about the meaning; avoid making mental comments and reflecting on the quality of your interpreting. Despite the differing value of such advice, all of the suggestions are based on one common premise: monitoring processes, or the control of speech production, are involved in interpreting and there is a necessary balance between the division of tasks, i.e. listening, monitoring and speaking, which must be attained to guarantee high-quality interpreting. Accordingly, the tasks must be controlled by capacity managing skills to ensure that they are not carried out to the detriment of one another. Achieving this balance of tasks is one of the main hurdles to overcome when learning how to interpret. This paper attempts to give insight into the monitoring processes that govern interpreting in order to increase the understanding and, in turn, facilitate the establishing of this balance.

Research has previously been done on the monitoring processes involved in adult second language production, notably by Stephan D. Krashen (1978, 1982, 1983). Although Krashen's Monitor Model is controversial and simplistic, dealing solely with the early stages of language acquisition and describing cognitive processes globally, it can provide a basic framework for the elaboration of a monitoring model for interpreting. The model would be a useful tool for interpreter-trainees, as it would heighten their understanding of the capacity managing processes they carry out and, if necessary, assist in shifting the balance between them. Thus, in this paper, Krashen's model is first presented and then further developed in order to describe more accurately the monitoring processes specific to interpreting. The Efforts Model, developed by Daniel Gile to describe the interaction 
of the three aforementioned capacity managing skills, is introduced to elucidate the role monitoring processes play in relationship to other capacity managing processes.

\section{KRASHEN'S MONITOR MODEL}

A Description

The Monitor Model is a hypothesis describing how the production of utterances in a second language is controlled. According to Krashen's model, when an utterance is produced in a second language, it is initiated by the acquired system, i.e. the system that has been established through use of the language in its natural environment. However, before final production, the monitor, i.e. the system based on classroom learning, is employed to control and introduce required changes in the utterance.

The monitor can also come into play after the utterance has been produced, in which case the process is termed self-repair (30). Rod Ellis describes the monitor as the "device learners use to edit their language performance." The monitor "utilizes learnt knowledge by acting upon and modifying utterances generated from acquired knowledge. This can occur either before the utterance is uttered or after" (1986: 262).

The Monitor Model is comprised of the five following elements: the acquisitionlearning hypothesis, the natural order hypothesis, the monitor hypothesis, the input hypothesis and the affective filter hypothesis (Ellis 1986: 261-263). Other than the monitor hypothesis, which is described above, the acquisition-learning hypothesis and the affective filter hypothesis are of interest in the interpreting context and are thus briefly described below.

The acquisition-learning hypothesis postulates that acquisition occurs subconsciously as a result of participating in natural communication where the focus is on meaning. Learning occurs through conscious study of the formal characteristics of the language. In storage, acquired knowledge is normally located in the left hemisphere of the brain in the language areas; it is available for automatic processing. Learnt knowledge is metalinguistic in nature. It is also stored in the left hemisphere, but not necessarily in the language areas; it is available only for controlled processing. Therefore, acquired and learnt knowledge are stored separately. In performance, acquired knowledge serves as the major source for initiating both the comprehension and production of utterances. Learnt knowledge is available only by the monitor (Ellis 1986: 261). Acquired knowledge is therefore of greater value to the interpreter, it being easier to access and utilize.

According to the affective filter hypothesis, the presence or absence of factors such as motivation, self-confidence or anxiety affect the ability to learn and use a foreign language (Ellis 1986: 263). These factors also play a role in interpreting, where motivation and self-confidence assist the interpreter in coping with stress. There are also indications that high anxiety and low self-confidence constitute personality factors typical of the monitor overuser, as described below.

Krashen defines three conditions that must be met for monitor use (1982: 16). First, sufficient time is a prerequisite for recalling and applying conscious rules effectively. Hence, overuse of the monitor leads to a hesitant style of speaking and inattention to what the interlocutor is saying. In addition to having sufficient time, the monitor user must also focus on form and correctness. In this case, how the speaker says something takes precedence over what the speaker is saying. Finally, in order to apply a rule, one must know the rule in advance; this is a formidable requirement if native level competence is the goal, since it is virtually impossible to define complex linguistic systems on the basis of rules alone.

Krashen also notes individual variation in monitor use (1982: 18-19). Monitor overusers often correct themselves in the middle of utterances and are so concerned with correct form that no fluency to speak of is achieved. Overuse can have two different causes. 
Firstly, the speaker may have had language instruction that focused only on grammar and never had the opportunity to acquire. The second reason is personality factors. Despite having had an opportunity to acquire, these overusers do not trust their innate competence and, in order to feel secure, constantly resort to the monitor to avoid mistakes. Monitor under-users, in contrast, simply do not utilize the monitor even when conditions allow it; they remain uninfluenced by error correction and allow themselves to be guided by subconscious, subjective criteria, such as a feeling or the way it sounds, to produce correct speech. These speakers rely completely on the acquired system. Last but certainly not least, optimal monitor users make use of their learned competence as a supplement to their acquired competence when the three conditions described above allow it and fluency remains unobstructed.

\section{Acquired and Learned Language Systems: Criticism of the Monitor Model}

Krashen's Monitor Model has been criticized in the past. To a considerable extent, this criticism centers on aspects of the initial stages of second language acquisition and is therefore not directly applicable to interpreting studies. However, a main point of controversy is of note: Krashen's strict division of the acquired and learned language systems (Ellis 1986: 265). Morrison and Low describe what they term a critical faculty (qtd. in Ellis 1986: 265), the speaker's critical awareness of what he or she has produced or is producing, in the form of a subconscious system that allows control. Morrison and Low state that the form of utterance can be attended to without applying conscious rules and without necessarily being able to make explicit how modifications are made in the initial output. Therefore, according to this theory, monitoring also takes place on a subconscious level.

Ellis also criticizes that the Monitor Model is still essentially a black box theory: Krashen describes neither what happens to acquired or learned input nor the cognitive processes involved in information processing and, therefore, does not explain exactly how the monitor operates $(1986: 265)$.

\section{Applying the Monitor Model to Interpreting}

In applying the Monitor Model to interpreting, it is useful to assume that there are two kinds of monitors as Morrison and Low propose: a conscious one for learned language ability and a subconscious one for acquired language ability. The acquired system would then be subject to monitoring processes separate from those of the learned system. Furthermore, when the three prerequisites for monitor use, time, form and rules, are discussed in the context of interpreting, it becomes apparent why this distinction is valuable. In interpreting, especially simultaneous, little time is available for conscious monitoring. When focusing on form, the interpreter is comparing output with input and focusing on syntax in the TL. Register, collocation and voice quality are also questions of form. Knowledge of rules applies not only to grammar but can be reformulated as knowing the equivalent expression in the TL. Knowledge of topic and terminology is, of course, necessary for the monitor to function. With such numerous and diverse processes being carried out, conscious reflection on individual elements merely hampers the interpreter. It can safely be assumed that conference interpreters employ primarily the subconscious monitor as a type of reflex. According to the above mentioned definition of Morrison and Low, the subconscious functioning of the monitor would not exclude the interpreter being critically aware of the decisions he or she makes.

Rather than consisting of separate elements, the ideal monitor in interpreting is better regarded as a single, comprehensive, subconscious system of integrated components that control individual operations. At the semantic level there are the cross-language processes that judge the adequacy of output. Lexical factors monitored include register and collocation. Grammar is a syntactic element. Phonetic elements are accent and voice quality. 
Finally, the reaction of the audience is also monitored to judge the overall interpreting performance while still in progress. The monitoring model described is a theoretical scenario in which each element is of equal importance. In a real-life situation, additional factors such as personality make-up and individual aptitudes play a substantial role in how the monitoring processes operate, some interpreters, for example, having a better grasp of the topic being discussed or experiencing greater affinity with the speaker. In fact, the modi operandi of interpreters may vary considerably, some personality types employing the conscious monitor more frequently than others and not impeding output as a result. It is a matter of course that achieving an optimum balance of tasks is paramount in this context.

These differences between interpreters are also evident in the classroom. Drawing students' attention to the conscious and subconscious monitors and their numerous components allows them to heighten their awareness of the processes they are carrying out while interpreting. By assessing their use of the monitor, they can gauge their performances more accurately and focus on those areas where their greatest weaknesses lie.

Up to this point, Krashen's Monitor Model has been presented in the overall context of interpreting. There are, however, fundamental differences in the monitoring processes in the two main modes of interpreting, simultaneous and consecutive. Daniel Gile's Efforts Model can serve to elucidate them.

\section{GILE'S EFFORTS MODEL}

\section{Simultaneous Interpreting}

In 1988, Gile presented the Efforts Model as an attempt to describe the mental processes involved in interpreting (1988). It describes interpreting as a capacity managing exercise entailing the successful completion of the following operations (1991: 16-18):

$\mathrm{L}: \quad$ listening to and analyzing the source language ( $\mathrm{LR} ; \mathrm{R}=\mathrm{Requirement}$ );

$\mathrm{P:} \quad$ producing output in the TL (PR);

M: short term memory storage and retrieval of information for strategic or linguistic purposes, i.e. when storage of information is required for a certain time before restitution because of differences between the languages (MR).

Simultaneous interpreting can be expressed as a process consisting of these capacities, which Gile shows in the following equation:

$\mathrm{SI}=\mathrm{L}+\mathrm{P}+\mathrm{M}$

(SI $=$ Simultaneous Interpretation)

The amount of effort required for each task varies according to the text interpreted; each activity can be viewed as having a specific requirement that must be fulfilled. Hence, interpreting can be performed only if the total capacity requirement is less than or equal to the total available capacity:

$\mathrm{LR}+\mathrm{PR}+\mathrm{MR}=\mathrm{TR}<\mathrm{TA}$

(TR = Total Requirement; TA = Total Available Processing Capacity)

Problems arise in two cases:

1. Total available capacity (TA) is insufficient:

$\mathrm{LR}+\mathrm{PR}+\mathrm{MR}=\mathrm{TR}>\mathrm{TA}$

2. Capacity for one of the components is insufficient, in spite of the total available capacity being adequate:

$\mathrm{LR}>\mathrm{LA}$ or $\mathrm{PR}>\mathrm{PA}$ or $\mathrm{MR}>\mathrm{MA}$ 
The second case is pertinent in the context of the monitoring model. Gile gives two reasons for its occurrence: a momentary lapse of attention and/or mismanagement of processing capacity by the interpreter. Mismanagement can arise as the result of overusing the monitor and is associated with what Gile designates as data storage and retrieval operations. Excessive storage and retrieval time leads to an imbalance of efforts, as MR is favored to an extent that LR and PR can no longer be fulfilled.

\section{Consecutive interpreting}

Gile's Efforts Model for consecutive interpreting consists of two steps (1991: 21).

In step one, the capacity requirements are listening, note-taking and memory operations:

Interpretation $=\mathrm{L}+\mathrm{N}+\mathrm{M}$

( $\mathrm{L}=$ Listening; $\mathrm{N}=$ Note-taking; $\mathrm{M}=$ Memory Operations)

In contrast to simultaneous, short-term memory operations in consecutive are required mainly to bridge the time lag during note-taking rather than to assure mandatory storage due to syntactic differences between the languages. These processes can also be motivated by strategic considerations in the note-taking process.

Step two requires remembering, note-reading and production:

Interpretation $=\operatorname{Rem}+\operatorname{Read}+\mathbf{P}$

(Rem $=$ Remembering; Read $=$ Note-reading; $P=$ Production $)$

The Rem component refers to the effort devoted to recalling the successive parts of the original speech and is therefore not equivalent to the short-term $\mathrm{M}$ component. As in simultaneous, total available capacity must be greater than or equal to the total requirement, and the capacity of each element must be greater than or equal to the individual requirements:

1. $\mathrm{LR}+\mathrm{NR}+\mathrm{MR}<\mathrm{TA}$

2. $\mathrm{LR}<\mathrm{LA}$ and $\mathrm{NR}<\mathrm{NA}$ and $\mathrm{MR}<\mathrm{MA}$

\section{The Efforts Model and Monitoring Processes}

The Efforts Model allows an improved understanding of the differences in monitoring processes in simultaneous and consecutive interpreting. In contrast to simultaneous, there are two stages of monitoring in consecutive: in step one, as a part of the note-taking operations, then in step two, during remembering and production. In addition, the use of the conscious monitor to check content is possible to a limited extent in consecutive, since the interpreter has more time, albeit still a limited amount, between steps one and two to mentally review the textual content as well as textual structure.

Gile states that little is known about the development of total available capacity during interpreter studies and asks if capacity can be increased through proper training (1991: 17-18). If the monitoring model is understood to be part of the MR, correct coaching of its use can lead to an improved balance of efforts, therefore freeing capacity for LR and PR. This would constitute a redistribution, and not necessarily an increase, of overall available capacity, but could nevertheless assist in improving the interpreter's performance. An example would be acquiring learnt knowledge of the subject material interpreted, making a shift from the use of the conscious to the subconscious monitor possible. This transfer would reduce the amount of effort necessary for data storage and retrieval in MR, thereby increasing capacity available for LR and PR. 
SUMMARY: TOWARDS A MONITORING MODEL FOR INTERPRETER-TRAINEES

Monitoring processes are only one aspect of interpreting; yet, as demonstrated, the misuse of the monitor can lead to an imbalance of efforts, jeopardizing the overall quality of the interpreting. Therefore, a monitor model can serve as a useful tool in interpreting studies. Indeed, interpreter-trainees should be made more aware of monitoring processes involved in language production so that they can use their monitors advantageously while in the booth.

A monitor model for interpreting must include the following elements: adequacy of the expression in the TL, collocation, register, grammar, accent, voice quality and the evaluation of the audience's reaction. Moreover, it should be conveyed to students that, ideally, the subconscious monitor dominates during performance and the conscious monitor is virtually eliminated, because the latter prevents the efficient utilization of other capacities by upsetting the balance of efforts. The SL and TL must be internalized or acquired to the point where monitoring at the subconscious level can occur; in an ideal scenario, knowledge of the topic and special terminology are also fully acquired. Further research into the difference between acquired and learned knowledge and language skills would be a valuable aid to the pedagogy of interpreting, since the ability to internalize language and knowledge quickly and efficiently is a key skill for interpreters. During a four-year course of studies, it may be of even more decisive importance for the successful conclusion of interpreter training than the language competence the student has when he or she first arrives at the university.

In addition, differences in the simultaneous and consecutive modes are to be considered. In consecutive, monitoring occurs during two stages: first during note-taking, then during production. The interpreter also has a limited amount of time between the two steps to use the conscious monitor and, if circumstances allow it, may even ask the speaker a question concerning an unclear point.

On the whole, awareness of monitoring processes can lead to an improved balance of efforts and, in turn, a more efficient use of available capacity, making the goal of highquality interpreting easier for trainees to reach.

\section{Notes}

1. The author is indebted to Dr. Donald Kiraly and Dipl.-Dolm. Volker Raatz for valuable comments and insights.

\section{REFERENCES}

ELLIS, Rod (1986): Understanding Second Language Acquisition, Oxford, Oxford University Press.

GILE, Daniel (1988); "Le partage de l'attention et le Modèle d'efforts en interprétation simultanée", The Interpreter's Newsletter, 1, pp. 27-33.

GILE, Daniel (1991): "The Processing Capacity Issue in Conference Interpretation", Babel, 37, pp. 15-27.

KRASHEN, Stephan D. (1978): "Individual Variation in the Use of the Monitor", Second Language Acquisition Research: Issues and Implications, William C. Ritchie (Ed.), New York, Academic Press, pp. 175-183.

KRASHEN, Stephan D. (1982): Principles and Practice in Second Language Acquisition, Oxford, Pergamon Press.

KRASHEN, Stephan D. and Tracy D. TERRELL (1983): The Natural Approach: Language Acquisition in the Classroom, Hayward, Alemany Press. 